BOGDAN WALCZAK

Akademia im. Jakuba z Paradyża w Gorzowie Wielkopolskim

\title{
Dialog pokoleń 2, pod redakcją Elżbiety Wierzbickiej-Piotrowskiej. Wydaw- nictwo Wydziału Polonistyki Uniwersytetu Warszawskiego, Warszawa 2016, ss. 359
}

W moim przekonaniu tom zasługuje na baczną uwagę wszystkich humanistów. Autentyczna interdyscyplinarność (o której jeszcze niżej) powoduje, że poszczególne prace wzajemnie się oświetlają i uzupełniają, tworząc wspólnie głęboko humanistyczny kontekst refleksji nad tytułowym zagadnieniem, skądinąd niesłychanie doniosłym pod względem społecznym, dialogu pokoleń. Tom zaleca się kilkoma cechami, które w moim przekonaniu w największym stopniu stanowią o jego wartości. Są to :

1) Wspomniana już wyżej autentyczna interdyscyplinarność. O dialogu pokoleń mówi się tutaj ze stanowiska językoznawczego, literaturoznawczego, kulturoznawczego, filozoficznego, pedagogicznego, etnologicznego itd. Zwraca uwagę to, że przedstawiciele wszystkich tych dyscyplin nie ograniczają się do przedmiotu, zakresu i metodologii własnej dyscypliny, są natomiast otwarci na bodźce i inspiracje płynące $\mathrm{z}$ dyscyplin sąsiednich. Właśnie dlatego interdyscyplinarność tomu określiłem jako autentyczną.

2) Niebagatelna wartość źródłowo-materiałowa. Większość prac poza skądinąd bardzo interesującymi rozważaniami ogólnometodologicznymi (z zakresu metodologii nauk humanistycznych) prezentuje rozległy materiał badawczy z różnych obszarów humanistyki, co stanowi o źródłowo-materiałowej wartości tomu.

3) Społeczna doniosłość problematyki tomu. Problematyka ta, jak też już nawiasowo wspomniałem wyżej, jest bardzo ważna w planie społecznym. Przyszłość każdej społeczności (każdej wspólnoty ludzkiej) zależy bowiem w rozstrzygającej mierze od niekonfliktowej, nieantagonistycznej komunikacji (prymarnie językowej, wtórnie w ogóle kulturowej) i wspótistnienia o charakterze przynajmniej wzajemnej tolerancji (lepiej : skutecznej i owocnej kooperacji) przedstawicieli różnych pokoleń. Społeczną wagę zagadnienia podnosi fakt, że współcześnie obserwujemy wielkie różnice, uwarunkowane głównie nowymi technologiami informatycznymi i komunikacyjnymi, między „światopoglądem” różnych generacji. Stąd dialog międzypokoleniowy (w każdym obszarze życia i kultury) jest niekwestionowaną potrzebą naszych czasów. Myślę, że recenzowany tom spełni w tym względzie swoje zadanie.

4) Różnorodność tematyczna, problemowa i metodologiczna. Tom, co wynika w dużej mierze z jego interdyscyplinarnego charakteru, imponuje różnorodnością tematyczną, pro- 
blemową i metodologiczną. Przeważa podejście kulturowe, które można uznać za jego zwornik. Za ważny i interesujący komponent tomu trzeba też uznać prace wykraczające poza wewnętrzną problematykę polską - o dialogu pokoleń i sytuacji polszczyzny poza jej granicami etnicznymi, na przykład na dawnych Kresach północno-wschodnich czy na Zaolziu, a także pracę o relacji : użytkownicy języka polskiego a imigranci w Polsce (niezależnie od tego, czy tego chcemy, czy nie chcemy i nie akceptujemy, imigranci już stanowią ważny problem społeczny, a w przyszłości jego waga może tylko rosnąć).

5) Wreszcie osobowość i ranga naukowa współautorów tomu. Spotykamy wśród nich wielkie nazwiska różnych dyscyplin humanistycznych. Spośród najlepiej mi znanych językoznawców zwrócę uwagę na Stanisława Gajdę, śp. Krystynę Długosz-Kurczabową, Halinę Zgółkową, Halinę Kurek, Halinę Karaś czy Irenę Jaros, a z młodszego pokolenia Błażeja Osowskiego, Justynę Kobus, Katarzynę Dróżdż-Łuszczyk, Ewę Kozioł-Chrzanowską, Magdalenę Pudę-Blokesz czy Elżbietę Wierzbicką-Piotrowską.

Tom jest, ogólnie rzecz biorąc, bezbłędny pod względem merytorycznym oraz staranny pod względem językowym i redakcyjnym. Niemniej jednak znalazło się w nim kilka drobnych błędów :

s. 82: zamiast detonat winno być denotat,

s. 84: przestarzałe to kwalifikator (w tym wypadku chronologiczny), a nie kwantyfikator,

s. 86: nic nie jest zaimkiem nieokreślonym,

s. 86: maksyma relewancji jest autorstwa Grice'a, a nie Grace,

s. 90: leksem prawica nie jest formą przestarzałą wyrazu prawy,

s. 176: prasłowiańskie *posagъ nie znaczy 'przypinać' (bo to nie czasownik, lecz rzeczownik). W cerkiewnosłowiańskim niemożliwa jest forma posage,

s. 345: doładowanie pochodzi od doładować, a nie od ładować,

s. 246: zamiast „frazeologia lub słownictwo” powinno być „frazeologia i/lub słownictwo", bo w gwarze młodzieżowej swoiste jest i słownictwo, i frazeologia.

Gdy chodzi o stronę formalną, zdarzają się usterki interpunkcyjne (brak przecinka) oraz redakcyjne (brak kursywy - czy w ogóle jakiegoś wyróżnienia typograficznego - w wypadku wyrazów lub morfemów użytych metajęzykowo). Oczywiście te drobne usterki nie wpływają na ogólnie wysoką ocenę tomu. 